\title{
Potential biodiversity change in Central Asian grasslands: scenarios for the impact of climate and land-use change
}

\author{
Sarahi Nunez ${ }^{1}$ (I) $\cdot$ Rob Alkemade $^{1,2} \cdot$ Kasper Kok $^{3} \cdot$ Rik Leemans $^{1}$ \\ Received: 5 July 2019 / Accepted: 16 February 2020 / Published online: 18 March 2020 \\ (C) The Author(s) 2020
}

\begin{abstract}
Central Asian grasslands are extensively used for pastoral livestock grazing. This traditional land use is nowadays characterized by intensifying grasslands into more productive pastures. This change affects biodiversity and diminishes grasslands' ecological role. Biodiversity impacts are probably also exacerbated by climate change. These changes in biodiversity are poorly studied in Central Asia. Here, we estimated potential biodiversity changes in the Central Asian grasslands using the latest shared socioeconomic pathways and the representative concentration pathways (i.e., SSP-RCP scenario framework). We selected scenarios with contrasting socio-economic and climate conditions (i.e., SSP1-RCP4.5, SSP3-RCP8.5, SSP4-RCP4.5, and SSP5-RCP8.5) and further detailed the land-use scenarios for the region using stakeholders' input. We indicated future biodiversity by the mean species abundance indicator. The contrasting scenario combinations showed that grasslands' biodiversity will decline under each scenario. The strongest impact on biodiversity is expected in SSP5-RCP8.5, where half of the grasslands are likely to lose most of their local originally occurring species by 2100. The lowest impact is expected in SSP4-RCP4.5. Our study stresses the potential vulnerability of this region to increasing land-use intensity and climate change. These impact projections can help regional decision makers to develop and implement better biodiversity-conservation and sustainable management policies for these grasslands.
\end{abstract}

Keywords Biodiversity change $\cdot$ Grasslands $\cdot$ Grazing intensification $\cdot$ Land-use scenarios $\cdot$ Climate change

Communicated by Wolfgang Cramer

Electronic supplementary material The online version of this article (https://doi.org/10.1007/s10113-020-01619-4) contains supplementary material, which is available to authorized users.

Sarahi Nunez

sarahi.nunezramos@wur.nl

Rob Alkemade

rob.alkemade@wur.nl

Kasper Kok

kasper.kok@wur.nl

Rik Leemans

rik.leemans@wur.nl

1 Environmental Systems Analysis Group, Wageningen University and Research, PO Box 47, 6700 AA, Wageningen, The Netherlands

2 PBL-Netherlands Environmental Assessment Agency, PO Box 30314, 2500 GH, The Hague, The Netherlands

3 Soil Geography and Landscape Group, Wageningen University and Research, PO Box 47, 6700 AA, Wageningen, The Netherlands

\section{Introduction}

Grasslands are among the world's most impacted ecosystems, largely because changes in land use and climate have mainly decrease biodiversity (Newbold et al. 2016; Newbold 2018). The grasslands of Central Asia, considered the most extensive grassland region in the world, are no exception as they are nowadays transformed by climate and land-use changes (Suleimenov 2014; Zhang et al. 2018a). These changes diminish these grasslands' ecological and socio-economical roles and this ultimately leads to biodiversity loss (Chen et al. 2019).

The Central Asian grasslands provide important habitats for many species that are of global and regional conservation concern (IUCN 2019), including steppe birds (Kamp et al. 2009; Kamp et al. 2011), large ungulates such as the Saiga tatarica (Mallon and Zhigang 2009), and diverse plant communities (Kamp et al. 2016). These grasslands also provide livelihoods for pastoral and agro-pastoral communities that lived in this region for centuries (Mirzabaev 2013; Mirzabaev et al. 2015). 
Traditionally, the Central Asian grasslands were used for extensive livestock production with high livestock mobility (FAO 2007), which was a key element to sustainably manage grasslands (Robinson et al. 2003; Robinson et al. 2016). After the collapse of the Soviet Union in 1991, large-scale land abandonment of agricultural areas designated for wheat cultivation leads to lower intensity of land use throughout the region, which may positively affect biodiversity (Kamp et al. 2012). Recently, however, land abandonment trends are slowing and the traditional mobile pastoralism is being replaced by collective and sedentary grazing systems. This intensified grazing leads to substantial changes in the vegetation structure and composition of these grasslands. Slight intensification could be beneficial for biodiversity particularly in relation to decreasing occurrence of wildfires, but in general, biodiversity is negatively affected (e.g., habitat degradation) (Mallon and Zhigang 2009; Singh et al. 2010; Kamp et al. 2016), especially in areas near settlements (Suleimenov 2014; de Beurs et al. 2015; Mirzabaev et al. 2015). These unique challenges related to biodiversity have been explored through species-specific responses for different taxonomic groups (Kamp et al. 2012; Brinkert et al. 2016).

Land-use change has been accompanied by a decadal temperature increase of $0.4{ }^{\circ} \mathrm{C}$ since 1970 (Chen et al. 2009; Hu et al. 2014). This temperature increase already substantially decreased grassland extent in the neighboring Xinjiang province in China since the start of this century (Zhang et al. 2018a). Climate change is expected to further exacerbate the land-use change impacts as the temperature in the region is projected to increase between 3 and $5{ }^{\circ} \mathrm{C}$ by 2080 , relative to the average temperature over the period from 1961 to 1990 (Lioubimtseva and Henebry 2009).

Future changes in land use likely pose considerable additional threats to Central Asia's biodiversity. These changes stem, for example, from the governmental support to enhance the livestock industry (Suleimenov 2014) or from an increasing future demand for livestock products (Herrero et al. 2009; Thornton 2010; Alkemade et al. 2013). Both factors are driven by population growth, economic development, and politics (Popp et al. 2017).

Central Asia been challenged socially, economically, and politically since the collapse of the Soviet Union in 1991 (Yu et al. 2019), and neighboring countries such as Russia and China have much at stake in Central Asia in terms of security and access to natural resources. The future outlook of, e.g., transboundary water governance, fossil fuel exploitation, and (regional) food security is complex and uncertain and of importance beyond the region itself. These issues are closely intertwined with land use and thus with biodiversity.

Central Asia is a region with large information gaps of past and current biodiversity trends, including habitat extent and intactness and species conservation status (Hamidov et al. 2016; IPBES 2018). These knowledge gaps exist mainly because available assessments poorly represent this extensive grassland area. Global assessments inadequately depict the more subtle changes in grasslands, such as increasing landuse intensities (that are driven by socio-economic factors). Furthermore, these assessments generally ignore interaction mechanisms between land-use and climate effects, and consequently fail to accurately project biodiversity change. Thus, a new approach that fills in these knowledge gaps and improves future projections is clearly needed.

Our study aimed to estimate potential change of biodiversity in the Central Asian grasslands as a result of the impacts of socio-economic trends and the consequent projections of land use and climate change. Our approach included the use of scenarios that are based on the shared socio-economic pathways (SSPs: O'Neill et al. 2014) and the representative concentration pathways (RCPs: van Vuuren et al. 2011), to quantify the possible range of future biodiversity changes. Scenarios have been widely used to assess global biodiversity change (e.g., Thomas et al. 2004; Malcolm et al. 2006; Pereira et al. 2010; IPBES 2018). They describe plausible futures based on a coherent and internally consistent set of assumptions about the drivers of change (MA 2005). These drivers are input to models that quantify and simulate projections of biodiversity change (IPBES 2016). We used the relative mean species abundance (MSA) of original species as compared to their original abundance to indicate biodiversity change (c.f. Alkemade et al. 2009). The projected continuous decline in biodiversity has consequences for current and future grassland management and conservation.

\section{Methodology}

\section{Study area}

The study area covered the grasslands of Central Asia. These grasslands are located in a large land-locked region comprising five post-Soviet independent republics of Kazakhstan, Kyrgyzstan, Tajikistan, Turkmenistan, and Uzbekistan. This region extends over an area of 4 million $\mathrm{km}^{2}$ and grasslands occupy nearly $65 \%$ of this extent, covering considerable areas of Kazakhstan, Tajikistan, and Kyrgyzstan (Fig. 1). The current total population of Central Asia is 71.3 million (World Bank 2019). Uzbekistan is the most populous country, followed by Tajikistan, Kyrgyzstan, Turkmenistan, and Kazakhstan (see Section S1 in Supplementary material). Currently, Kazakhstan holds the largest GDP in the region (179.3 billion current US\$ and per capita 9812.6 current US\$ in 2018) and Tajikistan the lowest (7.5 billion current US\$ and per capita 826.6 current US\$ in 2018) (World Bank 2019).

Most grasslands are arid and semiarid (Gintzburger et al. 2005; FAO 2007) and are suited to extensive livestock production. Livestock production in Central Asia mainly consists 


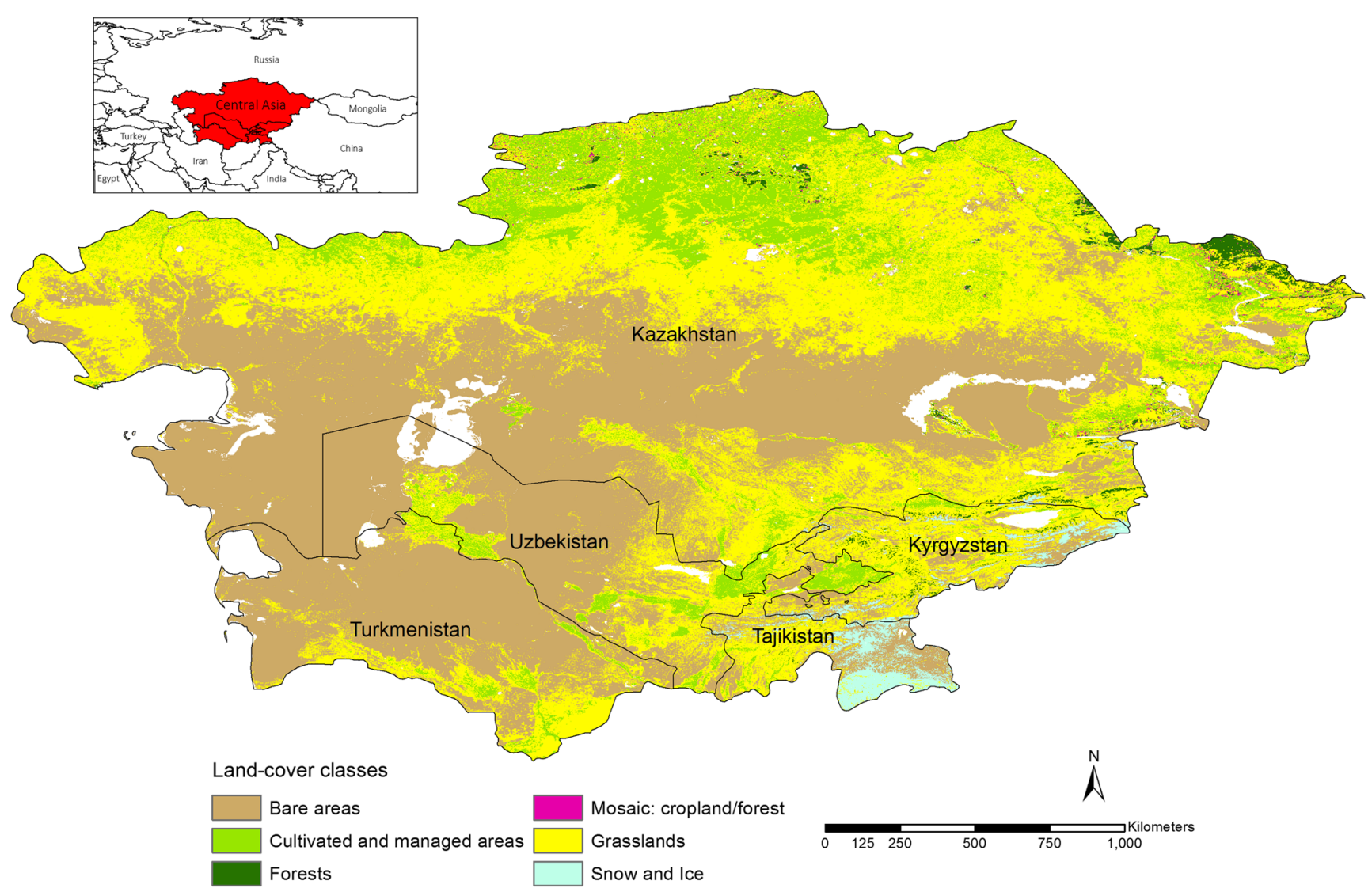

Fig. 1 Map of Central Asia and main land-cover classes (adapted from GLC2000, Global Land Cover Network)

of cattle and sheep, and to a lesser extent chicken, pigs and goats (FAO 2007). Crop production in the region includes irrigated and rainfed cropland. Irrigated agriculture is dominated by the production of cotton in Turkmenistan, Uzbekistan, and Tajikistan, and wheat mainly in Kazakhstan. Saline soils are common across the semiarid and arid areas of Central Asia (ZEN 2011).

Currently, more than $20 \%$ of the natural grasslands of Tajikistan, Turkmenistan, and Uzbekistan are under moderate to high grazing intensity, while the vast majority of grasslands of Kazakhstan and Kyrgyzstan are nearly pristine natural grasslands with low grazing intensity (estimated from Petz et al. 2014). Grasslands in Kazakhstan, the largest country in the region, have possibilities to increase livestock production due to available biomass resources, especially in the east and the northwest (Hankerson et al. 2019).

\section{Study approach}

In order to assess biodiversity change in grasslands, we developed a stepwise approach to combine data sources on land-use change and climate change (Fig. 2). First, we developed qualitative land-use scenarios for the region based on scenario approach. Then, we projected grazing intensity for different scenarios and analyzed grazing patterns with a spatial modeling approach. Finally, we assessed the potential impacts on biodiversity using the GLOBIO approach. Below, we describe these steps and data sources in more detail.

\section{Step 1. Developing land-use scenarios for Central Asia}

We developed a set of four land-use scenarios based on the Central Asian socio-economic narratives from the European FP7 project IMPRESSIONS (Harrison et al. 2019). These socio-economic narratives are plausible 'high-end' qualitative stories, which contain additional, more detailed information about regional socio-economic drivers of change (i.e., population and gross domestic product: GDP) for 2010 to 2100 . The land-use scenarios were developed following socioeconomic narratives that resulted from two stakeholder workshops held in Central Asia. The first workshop was held in Almaty in 2015 with the contribution of 23 regional stakeholders and the second one in Baku in 2016 with the contribution of 26 regional stakeholders (Kok and Pedde 2016). The participatory stakeholder involvement process aimed at better representing regional perspectives on plausible future developments.

The scenario selection made within the IMPRESSIONS project was based on the most recent global climate scenarios 
Fig. 2 Schematic illustration of the study approach to assess biodiversity change in grasslands

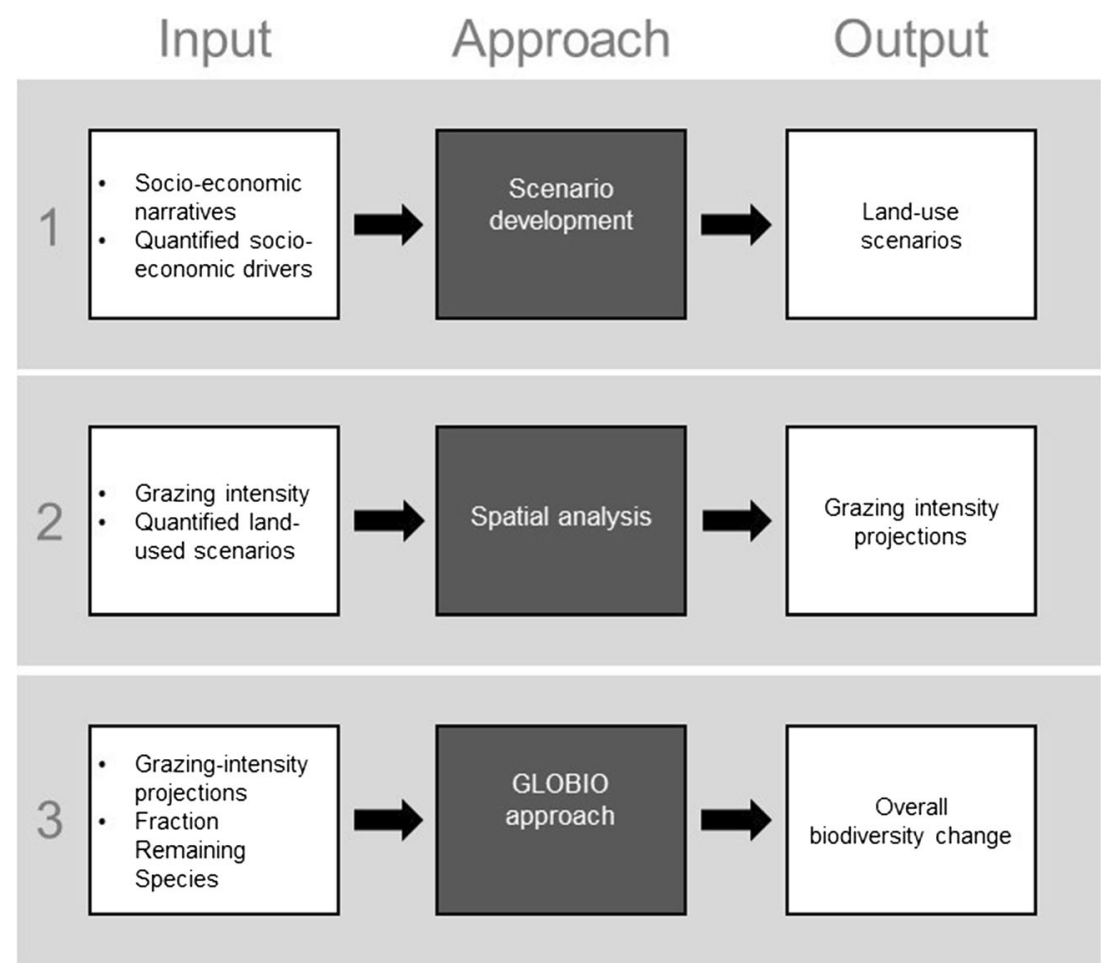

including both socio-economic future outlooks (shared socioeconomic pathways, or SSPs: O'Neill et al. 2014) and climatic change projections (representative concentration pathways, or RCPs: van Vuuren et al. 2011). Four SSPs were developed for Central Asia, including SSP1 (sustainability) and SSP4 (game of elites) combined with RCP4.5, and SSP3 (regional rivalry) and SSP5 (fossil-fuelled development) combined with RCP8.5 (Fig. 3). SSP1 represented low and constant population growth and moderate economic growth. SSP4 represented low population growth and economic stagnation. Climate change was moderate in both SSP1 and SSP4. SSP3 and SSP5 scenarios represented high population growth, with economic stagnation and high economic growth, respectively. Both SSP3 and SSP5 were challenged by high climate change.

Our land-use scenarios described the impact of socioeconomic drivers and model assumptions (i.e., technological agricultural development) on grasslands. Technological agricultural development was denoted by the management factor which is derived from the IMAGE model (Stehfest et al. 2014). The model assumptions indicate that technological agricultural development improves agricultural practices that lead to better yields, and hence to a higher management factor. This factor slightly improved in SSP1 and remained constant in SSP3, whereas in SSP4, it declined, and in SSP5, it only improved in the second half of the century.

Land-use change was indicated by the extent and intensity of grassland use (i.e., grazing intensity). Grazing intensity results from an increase of the relative stocking rate of livestock, the carrying capacity of the ecosystems, and additional management of the land (Alkemade et al. 2013). In this study, we used grazing intensity derived by Petz et al. (2014). They calculated grazing intensity as the ratio between biomass grazed by different livestock types (i.e., cattle, buffalo, sheep, and goat) and biomass available (net primary production) for grazing. The grazed biomass is the plant biomass consumed by livestock and depends on livestock density. The available biomass depends on net primary production and on the biome's edibility. The dataset on spatial distribution of management intensity represents the current use of these grasslands (Petz et al. 2014). The management intensity ranges from 0 in areas with a low grazing intensity to 1 in areas with a high grazing intensity.

Step 2. Quantifying grazing intensity projections

We quantified changes in grazing intensity at a grid cell level in ArcGIS 10.5 for each SSP for three periods (i.e., 2010-2040, 2040-2070, and 2070-2100) as follows:

$\operatorname{GrazInt}_{i, t}=\operatorname{GrazInt}_{i, 0} \cdot \Delta \operatorname{Pop}_{i, t} \cdot \Delta G D P_{i, t} \cdot \Delta M F_{i, t}$

where GrazInt ${ }_{i, t}$ is the grazing intensity in grid cell $i$ at time $t$, GrazInt $_{\mathrm{i}, 0}$ is the current grazing intensity in grid $\mathrm{i}, \Delta \mathrm{Pop}_{\mathrm{i}, \mathrm{t}}$ and $\Delta \mathrm{GDP}_{\mathrm{i}, \mathrm{t}}$ are the relative increases of population and GDP per capita in grid cell $\mathrm{i}$ at time $\mathrm{t}$, and the relative increase change in the management factor $\left(\Delta \mathrm{MF}_{\mathrm{i}, \mathrm{t}}\right)$ in grid cell $\mathrm{i}$ at time $\mathrm{t}$. We assumed a multiplicative relationship between these four factors and grazing intensity. We classified the resulting grazing 


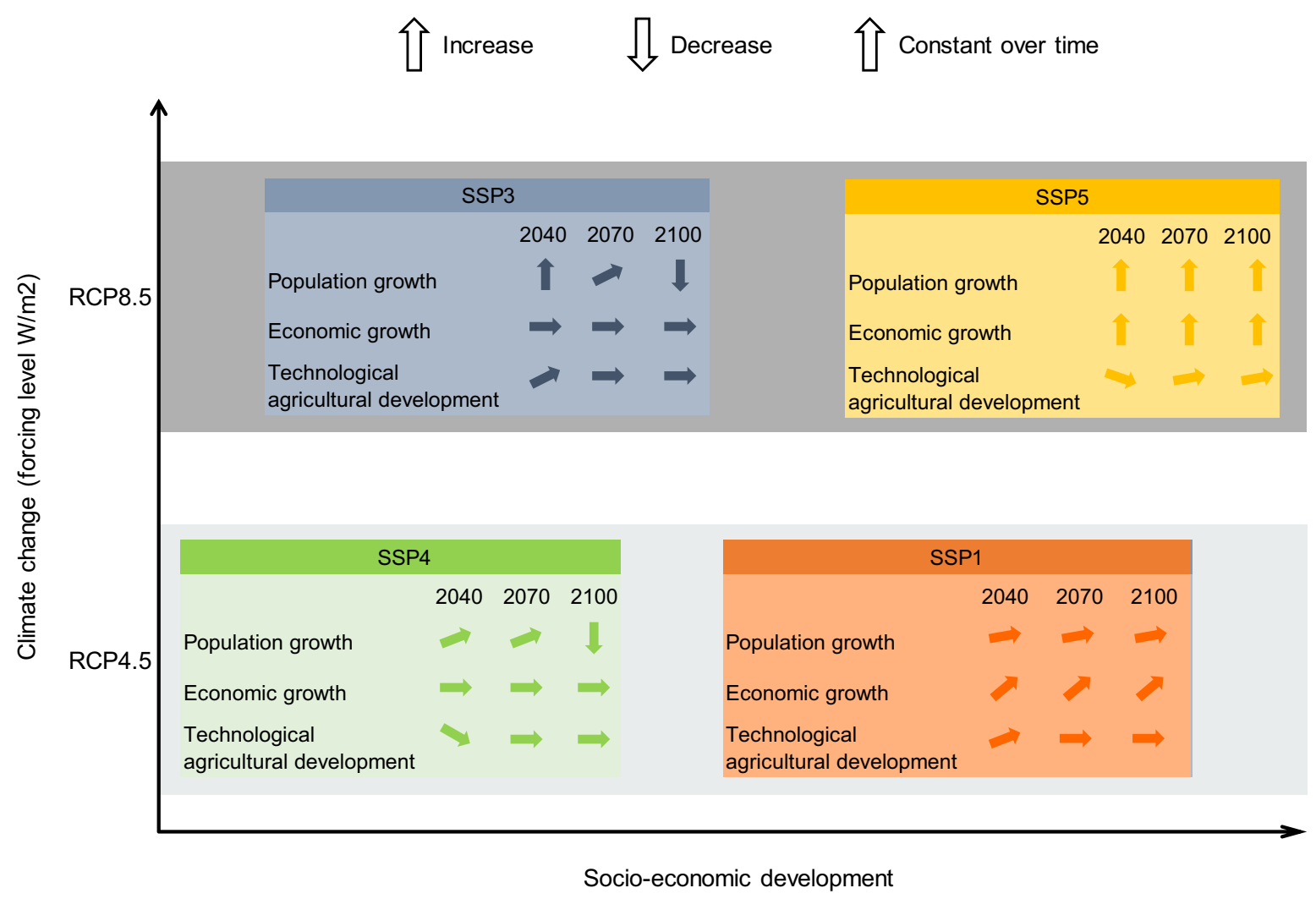

Fig. 3 SSP-RCP scenario matrix and the characteristics of major socio-economic drivers

intensity as low, moderate, high, and converted land. Following Petz et al. (2014) and Alkemade et al. (2013), low grazing intensity (i.e., 0.0 to 0.4 ) corresponds to nearly pristine natural grassland grazed by wildlife or domestic animals at rates similar to those of free-roaming wildlife. Livestock production in low grazed areas is far below the natural production capacity. Moderate grazing intensity (i.e., 0.4 to 0.6 ) corresponds to natural grassland with grazing-based production system; grazing has different seasonal patterns or vegetation structure is different compared with natural grassland. Livestock production is slightly below the natural production capacity. High grazing intensity (i.e., 0.6 to 1.0 ) means intensively used and (partly) modified natural rangelands with mixed production system; management heavily depends on external inputs and high resource extractions from the original ecosystems. Livestock production approaches or exceeds the natural production capacity and grazing is supplemented with feed application. And last, converted land corresponds to grasslands that exceed their grazing capacity (i.e., GrazInt $>1.0$ ).

\section{Step 3. Analyzing potential biodiversity changes}

We quantified grazing and climate change effects on biodiversity using the GLOBIO model. The core of the GLOBIO model consists of a set of quantitative relationships that assess the impacts of anthropogenic pressures on biodiversity, including climate change and land use (Alkemade et al. 2009; Schipper et al. 2019). Impacts are quantified based on the mean species abundance (MSA) metric, which is an indicative of local biodiversity intactness or naturalness. Thus, grazing and climate change effects were indicated by the MSA. The MSA metric is quantified based on data that describe the changes in community composition in relation to particular pressures and ranges between 0 in areas where original biodiversity has completely disappeared and 1 in areas where species composition and abundance are fully original. An overall MSA value is calculated by multiplying the MSA values corresponding with the individual pressures 1 to $m$, as indicated in Eq. 2 (Schipper et al. 2019):

$M S A_{s, i}=\prod_{x=1}^{x=m} M S A_{x, s, i}$

where $\mathrm{MSA}_{s, i}$ is the overall MSA for species group $s$ in grid cell $i$ and $\mathrm{MSA}_{x, s, i}$ is the MSA corresponding with pressure $x$ on species group $s$ in grid cell $i$. Increases in individual species abundance from reference to impacted situation are truncated to avoid the indicator being inflated by opportunistic or generalist species that benefit from habitat disturbance (Schipper et al. 2019).

MSA values for different grazing intensities are derived from data from an extensive literature review (Alkemade et al. 2009; Alkemade et al. 2013). This literature review 
included data-sets of species abundances from grazing land compared to surrounding natural grasslands (Wang et al. 2002; Sánchez-Zapata et al. 2003). Ratios of the abundance of single species found in disturbed and undisturbed grasslands with different grazing intensity were the basis on which to calculate mean species abundance (MSA) by calculating the arithmetic mean over all species present in the natural or reference situation. Ratios were truncating to 1 , if population size on grazed lands exceeds these from the natural grassland (Alkemade et al. 2013). A random-effects meta-analysis derived a pooled effect size for the different grazing intensities. MSA is conceptually similar to the biodiversity intactness index (Scholes and Biggs 2005).

We quantified potential biodiversity change from changes in grazing intensity (i.e., $\mathrm{MSA}_{\mathrm{LU}}$ ) based on the relationship between biodiversity intactness and grazing intensity (Alkemade et al. 2013; Petz et al. 2014). Such changes in grazing intensity result in, for instance, changing plantspecies composition, soil compaction by trampling, outcompeting and hunting of wildlife, homogenization of landscapes, and habitat destruction. Typically, biodiversity declines due to the impacts of anthropogenic pressures. However, an increase in biodiversity is possible if for instance land use becomes less intensive by means of a decrease of livestock densities.

The climate change effect on biodiversity (i.e., $\mathrm{MSA}_{\mathrm{CC}}$ ) was estimated using the relationship between global mean temperature increase and the fraction of remaining species (FRS), which is derived from a meta-analysis of almost 100 studies that projected species shifts in different speciesenvelope models (Nunez et al. 2019). This relationship is useful to assess relative adverse effects of different climate change scenarios and the magnitude of expected changes of biodiversity. We related the projected global mean temperature increase for RCP4.5 and RCP8.5 for three periods and the FRS estimate for grasslands (FRS $=-0.032,95 \%$ confidence interval: -0.048 to -0.017 ). This relationship determined changes of species richness in grasslands compared to the original biodiversity state.

Following the GLOBIO model, the overall potential of biodiversity change $\left(\mathrm{MSA}_{\mathrm{LU}-\mathrm{CC}}\right)$ was estimated by multiplying the individual effects of land-use $\left(\mathrm{MSA}_{\mathrm{LU}}\right)$ and climate change $\left(\mathrm{MSA}_{\mathrm{CC}}\right)$ in ArcGIS 10.5. We visually compared the spatial patterns of biodiversity change in grasslands. We analyzed these patterns by calculating the grassland proportion under each MSA category for each scenario for three periods to indicate the resulting biodiversity change.

\section{Data sources}

In this study, we used various datasets (qualitative and gridded) to explore land-use and climate change effects on the biodiversity of grasslands. We describe these sources below (see Section S2 in Supplementary material for more detail).

Population and GDP projections were quantified within the IMPRESSIONS project. Population projections are gridded datasets of $0.125 \times 0.125^{\circ}$ resolution (Jones and O'Neill 2013). GDP projections are datasets for each country derived from The World Bank DataBank (2016).

Technological development was based on the management factor from the IMAGE model. This management factor described the actual yield per crop group (i.e., grass) for Central Asia region as a proportion of the maximum potential yield and depends on the regional GDP (Stehfest et al. 2014).

Projected global mean temperature increases for the late twenty-first century relative to the 1986-2005 period for $\mathrm{RCP} 4.5\left(1.8^{\circ} \mathrm{C}\right)$ and $\mathrm{RCP} 8.5\left(3.7^{\circ} \mathrm{C}\right)$ were used to indicate climate change (IPCC 2013). Projected temperatures for the years 2040 and 2070 were derived from Table AII.7.5 (Annex II; IPCC 2013). The IPCC 5th Assessment Report used 18501900 as a historical baseline and estimated the warming from then to $1986-2005$ at $0.6{ }^{\circ} \mathrm{C}$.

The land cover database GCL2000 (Bartholomé and Belward 2005) and the terrestrial biomes database (Olson et al. 2001) were used to delineate grasslands and other land-use classes in the region.

\section{Results}

Our land-use scenarios showed that grazing intensification will potentially trigger large biodiversity changes in the region over the course of this century. SSP1 and SSP5 depicted the larger increases in grazing intensity by 2100 , while the other two scenarios featured moderate changes. These changes in grazing intensity translate into a decrease in the $\mathrm{MSA}_{\mathrm{LU}}$ (Fig. 4). The MSA 'high' corresponded to nearly pristine grasslands where the proportion of originally occurring species was projected to be $70-100 \%$ after land-use change, 'moderate' to grasslands areas that lost between 30 and $50 \%$ of the originally occurring species, 'low' to areas that lost more than half of their originally occurring species, and 'critical' indicated that areas lost almost entirely their local originally occurring species.

In SSP1, Central Asian countries followed a path of sustainable development with steady economic growth (see landuse scenarios in Section S3 in Supplementary material). However, the extent of natural grasslands that contain the highest biodiversity (i.e., low-intensity grazed) decreased by $8 \%$ between 2010 and 2100 (Table 1). Between 2040 and $2070,10 \%$ of the total grasslands likely converted, for example, into pastures, due to irrigation efficiency improvements. In SSP5, the highly intensively grazed areas increased by $6 \%$ between 2010 and 2100 and the moderate grazing areas by $9 \%$ (Table 1). By 2100, the extent of natural grasslands was highly 


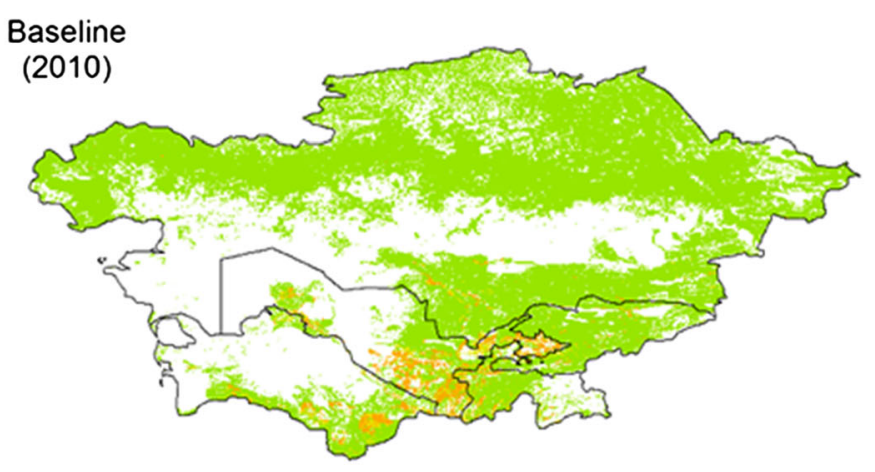

$N$

$M S A_{L U}$

\begin{tabular}{|c|c|}
\hline High & $(0.7-1.0)$ \\
\hline Moderate & $(0.5-0.7)$ \\
\hline Low & $(0.1-0.5)$ \\
\hline Critical & $(<0.1)$ \\
\hline
\end{tabular}

SSP1
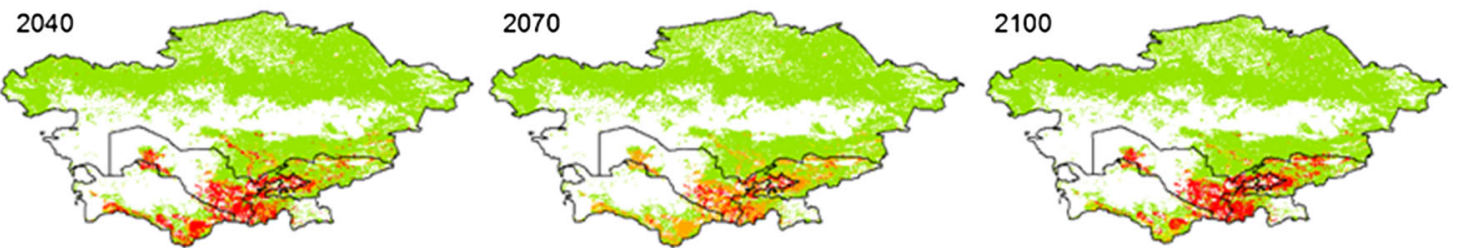

SSP3
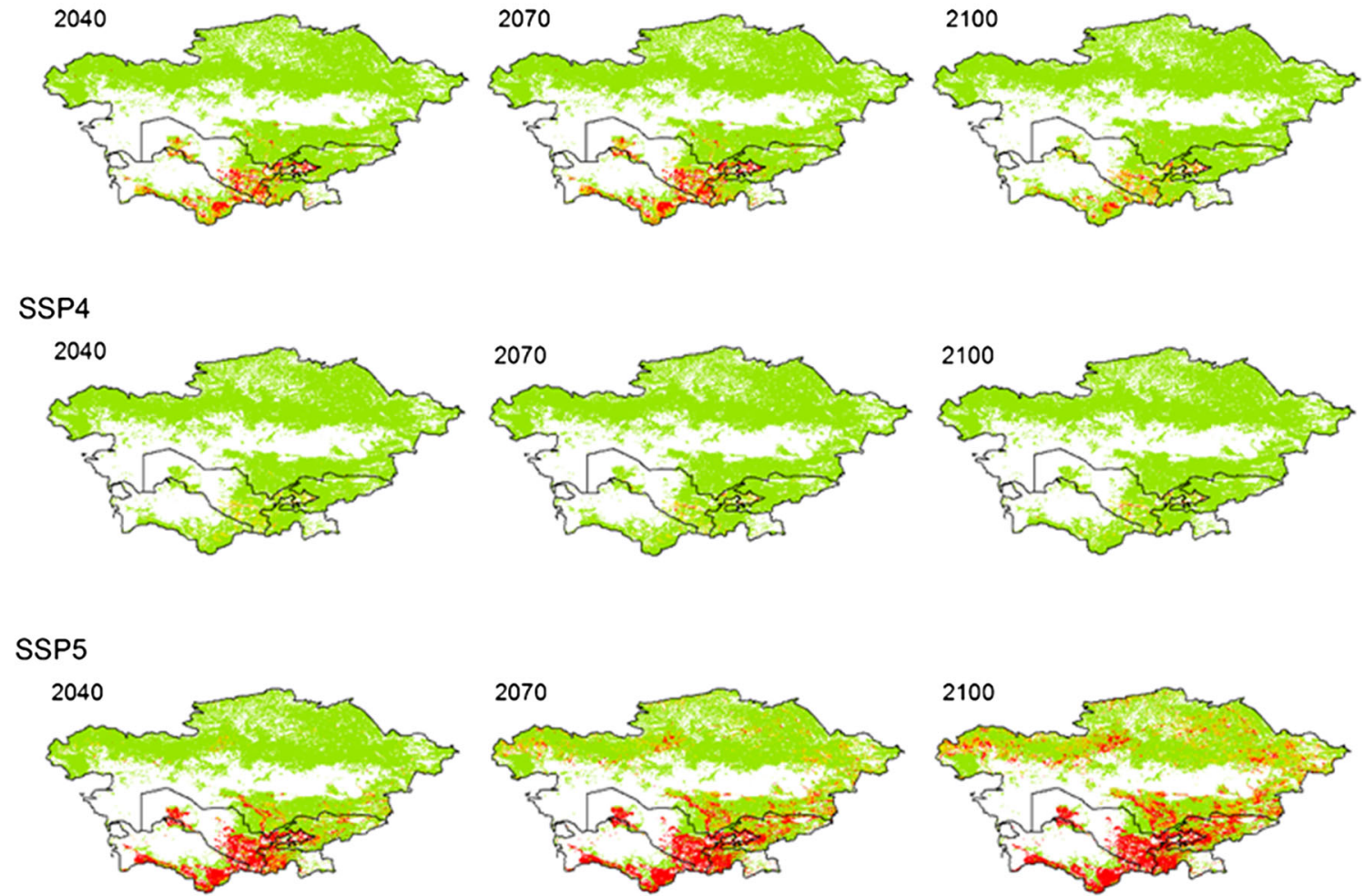

Fig. 4 Estimated changes in mean species abundance $\left(\mathrm{MSA}_{\mathrm{LU}}\right)$ in the grasslands of Central Asia between 2010 and 2100 for different futures

reduced and possibly converted into other categories. Changes resulted from high economic and population growth. By the end of the century, the total population in Central Asia increased from 63.0 million in 2010 to 74.5 million and the annual GDP was over 20 times higher than in 2010. SSP3 was characterized by both an exclusive economic development and limited cooperation between countries that limit the economic growth in the region. Between 2040 and 2070, population dynamics powered a moderate grazing intensification that decreased low-intensity grazed areas by $4 \%$ (Table 1). In 2100, however, grazing intensification decreased due to a limited economic growth and out-migration from the region. By then, 
Table 1 Changes in grazing intensity (\%) for all scenarios for 2040, 2070, and 2100

\begin{tabular}{|c|c|c|c|c|c|c|c|c|c|c|c|c|c|}
\hline \multirow[t]{2}{*}{ Grazing intensity } & \multirow[t]{2}{*}{2010} & \multicolumn{3}{|l|}{ SSP1 } & \multicolumn{3}{|l|}{ SSP3 } & \multicolumn{3}{|l|}{ SSP4 } & \multicolumn{3}{|l|}{ SSP5 } \\
\hline & & 2040 & 2070 & 2100 & 2040 & 2070 & 2100 & 2040 & 2070 & 2100 & 2040 & 2070 & 2100 \\
\hline Low & 94.4 & 85.0 & 84.9 & 86.3 & 91.1 & 90.1 & 94.5 & 97.3 & 97.9 & 98.1 & 83.1 & 71.0 & 59.3 \\
\hline Moderate & 2.2 & 2.8 & 2.3 & 2.4 & 2.6 & 2.6 & 2.2 & 2.2 & 1.6 & 1.4 & 3.6 & 8.2 & 11.6 \\
\hline High & 3.4 & 3.6 & 3.2 & 2.7 & 2.8 & 3.0 & 2.5 & 0.5 & 0.4 & 0.4 & 3.0 & 6.0 & 9.8 \\
\hline Converted & 0.0 & 8.5 & 9.6 & 8.7 & 3.5 & 4.3 & 0.8 & 0.0 & 0.1 & 0.2 & 10.3 & 14.7 & 19.3 \\
\hline
\end{tabular}

the population size in SSP3 was the lowest among all scenarios. In SSP4, Central Asia was a highly unequal heterogeneous region with an agricultural sector that focused on realizing the food demand by local populations. Grazing intensity only increased slightly as a result of low population and economic growth, and therefore did not show substantial impacts on the $\mathrm{MSA}_{\mathrm{LU}}$. On the contrary, the high intensity grasslands slightly decreased. This reduced the pressure on grasslands and slightly increased the $\mathrm{MSA}_{\mathrm{LU}}$. Here, livestock production probably expanded into other areas (e.g., croplands or forest). The grazing intensity in grid cells without population was assumed to remain constant (i.e., no changes in GDP per capita and the management factor).

RCP4.5 projected a global mean temperature increase of $2.4{ }^{\circ} \mathrm{C}$ relative to pre-industrial. This increase resulted in the $\mathrm{MSA}_{\mathrm{CC}}$ in grasslands decreasing from 2010 to 2100 by $16 \%$ (95\% confidence interval: 9-23\%). For RCP8.5, the global mean temperature increase was $4.3{ }^{\circ} \mathrm{C}$ relative to preindustrial and the $\mathrm{MSA}_{\mathrm{CC}}$ was projected to decrease by $27 \%$ (95\% confidence interval: $16-38 \%$ ). We estimated that the MSA $_{\text {LU-CC }}$ in grasslands decreased dramatically between 2010 and 2100 (Fig. 5). In 2100, only half of the natural grasslands of Central Asia was projected to remain undisturbed by land-use and climate changes for all SSPs.

The largest decrease in biodiversity occurred in SSP5RCP8.5. By 2100, half of the grasslands were likely to lose more than $70 \%$ of their local originally occurring species. This scenario projected the largest grassland conversion (i.e., 19\%) that implied a strong decline of more than $90 \%$ in the local originally occurring species (Fig. 6 and Table 2). In SSP3RCP8.5, biodiversity change occurred already in the first half of the century. This was mainly driven by population growth and food demand peaking in 2040. The high climate change impact exacerbated biodiversity loss in these two scenarios. Moderate changes in biodiversity in SSP1-RC4.5 were mostly driven by the increasing population and economic development. Last, the scenario SSP4-RCP4.5 projected the smallest decrease in biodiversity by the end of the century. In this scenario, most grasslands $(98 \%)$ retained more than half of their original occurring species, while less than $1 \%$ fell into a critical category. SSP1 and SSP4 were influenced by a less stringent climate change impact on grasslands.

\section{Discussion and conclusions}

Our analysis showed that biodiversity in the Central Asian grasslands has a high potential to change in all scenarios. The strongest impact on biodiversity was expected in SSP5RCP8.5. This was a high-end climate change scenario with high economic growth that intensively develops the agricultural sector. This finding is consistent with the recent IPBES report (IPBES 2019) that projects land-use and climate change impacts on biodiversity. This IPBES report indicates that species richness more strongly decreases in all SSPs-RCPs scenarios (with SSP5-RCP8.5 the strongest) for Central Asia in comparison to most other regions. Our results showed that the lowest impact will occur in Central Asia in SSP4-RCP4.5.

SSP1-RCP4.5 depicted a remarkably large biodiversity loss driven by the moderate economic and high demographic growth that lead to rapid grazing intensification. This result, however, contrasts the IPBES projections and its intuitive assumption that this scenario will protect biodiversity. Here, SSP1 showed that a world with high affluence and population growth will continue to put pressure on biodiversity, regardless of the efforts to pursue sustainability.

The extent of (nearly) pristine natural grasslands that contain the highest biodiversity was projected to be halved in all scenarios, already by 2040 . In terms of impacts on biodiversity, this means that the abundance of original occurring species decreases to less than $70 \%$ in half of the total grassland area. The remaining proportion of natural grasslands was projected to slightly change over the course of the century, with consequent implications in ecosystem functioning. This is consistent with previous studies (Christensen et al. 2004; Zhang et al. 2018b) that showed that small temperature increase (i.e., $1-2{ }^{\circ} \mathrm{C}$ ) and moderate grazing level in steppe will affect native grasses (e.g., bunch-grass steppe) and result in decreasing above ground net primary production.

Previous studies (Scholes and Biggs 2005; Kamp et al. 2012; Newbold et al. 2015; Brinkert et al. 2016) showed that agricultural intensification and degradation of grasslands negatively affected biodiversity in the past, with substantial reductions in the total abundance of species compared to primary vegetation. However, the long-term conservation of biodiversity is likely to require the maintenance of ecologically and 


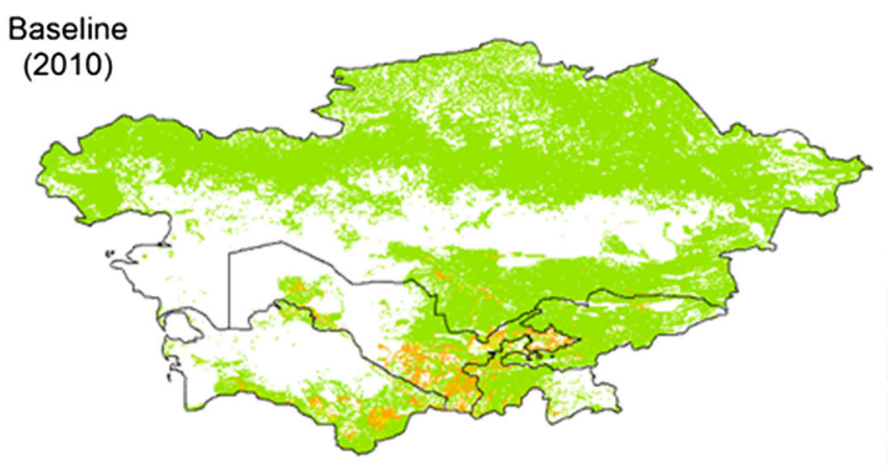

SSP1 - RCP4.5
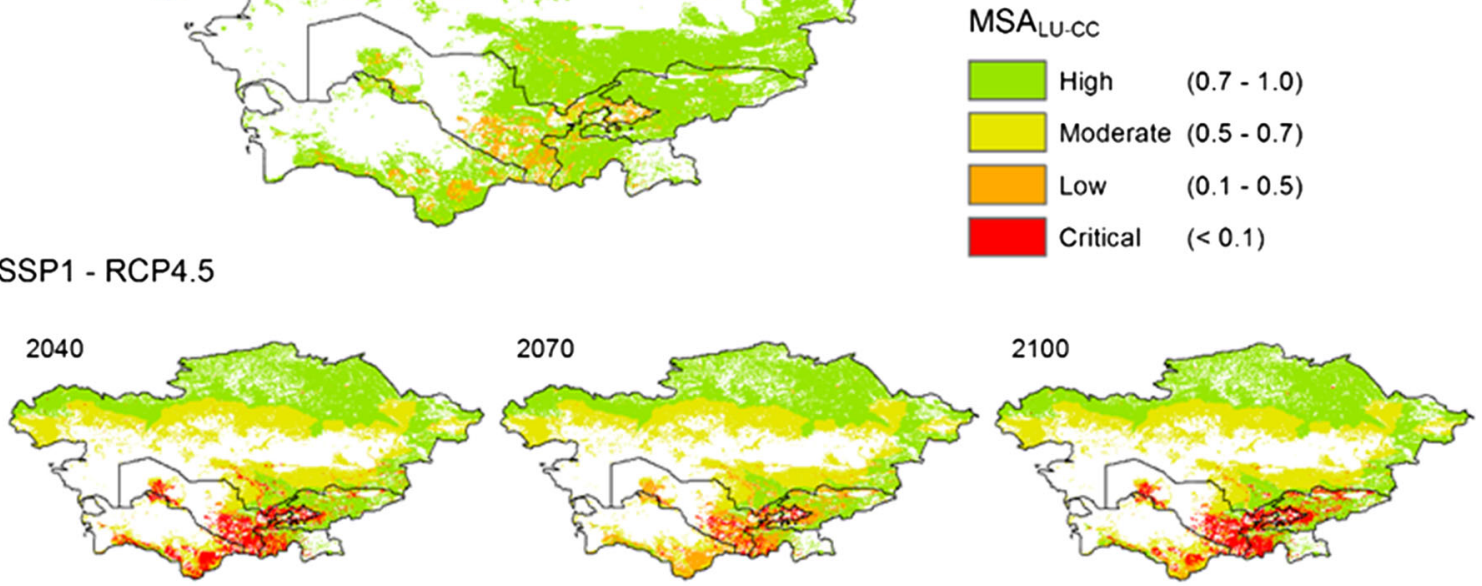

\section{SSP3 - RCP8.5}
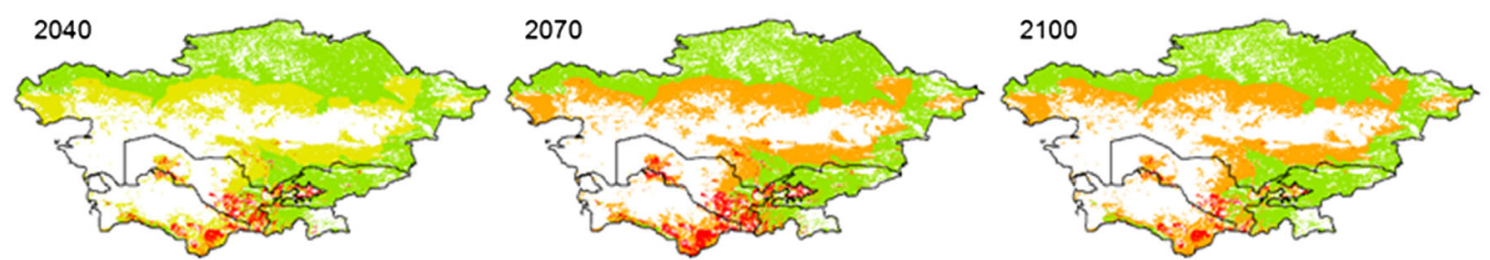

SSP4 - RCP4.5
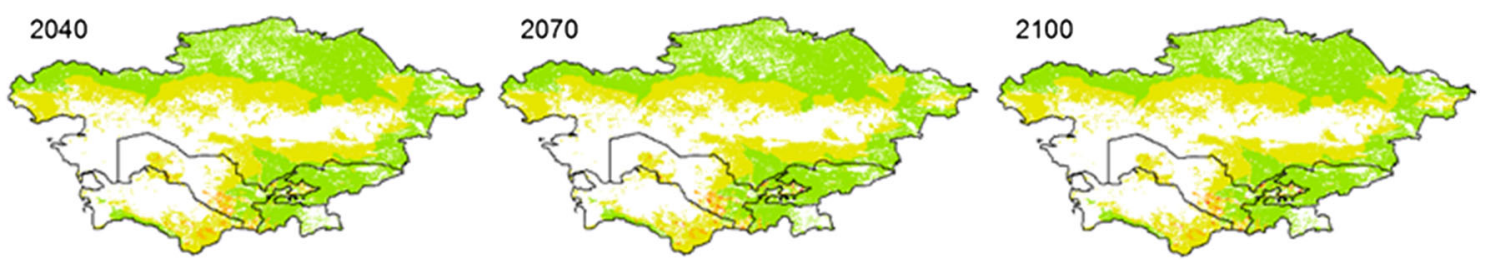

SSP5 - RCP8.5
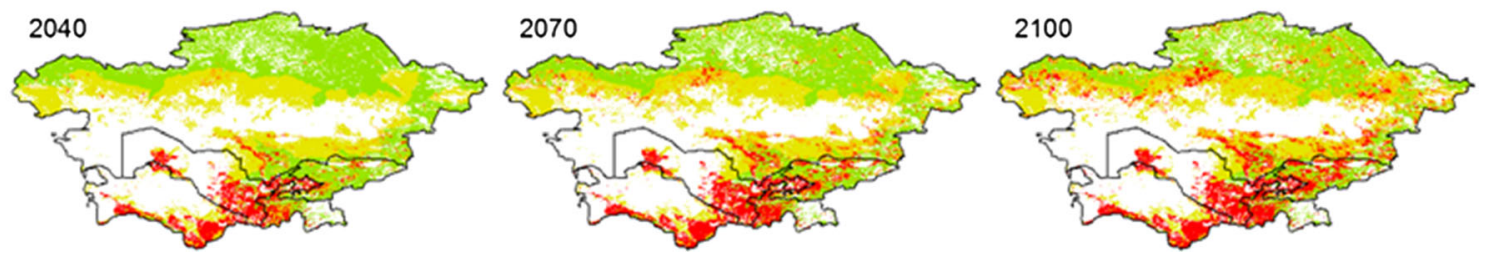

Fig. 5 Estimated changes in mean species abundance $\left(M_{\text {SSA-CC }}\right)$ in the grasslands of Central Asia between 2010 and 2100 for different futures

socially sustainable grazing systems, especially because of progressive abandonment of intensive agriculture in Central Asia (Sánchez-Zapata et al. 2003).

Abandoned arable fields are slowly recovering after abandonment during the collapse of the Soviet Union, and effects on long-term biodiversity change are unknown (Brinkert et al. 2016). Previous assessments of past and future land use in the region suggest that a slight intensification of free-ranging grazing systems would be beneficial to restore near-natural steppe communities across most of the study area (Kamp 
Fig. 6 Estimated changes (\%) in mean species abundance $\left(\mathrm{MSA}_{\mathrm{LU}-\mathrm{CC}}\right)$ for different SSPsRCPs between 2010 and 2100

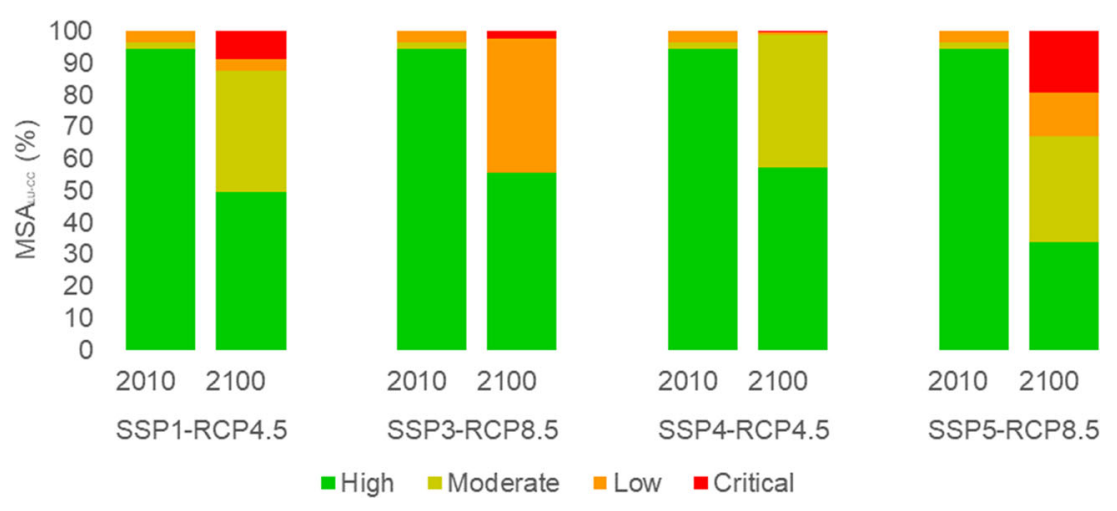

et al. 2009; Dara et al. 2019). This would be beneficial for specific steppe species (e.g., Sociable Lapwig) as well. While determining an intensification threshold is out of the scope of this analysis, we show that slight changes in climate and land use would not have substantial impacts on the overall species abundance in this region.

Critical levels of biodiversity loss were mainly projected around population settlements. This is because land-use change is increasingly dynamic in response to population growth (Verburg et al. 2015) and economic development, influenced by people's preferences for agricultural production and technological development (Kok et al. 2018). Thus, spatial patterns of the relative change in land use that drive great losses of biodiversity occurred mainly around urban areas. For example, scenarios with steep technological developments (i.e., SSP1 and SSP5) showed an increasing management intensity of grasslands, with possibly habitat conversion and eventually land degradation (Popp et al. 2017). In other words, natural grasslands that decreased will likely convert into moderate or even high intensively used grasslands, and these eventually into other land use (e.g., permanent pastures). This will typically cause a decrease of biodiversity (Alkemade et al. 2013; Hamidov et al. 2016). In contrast, scenarios that assumed gentle technological developments (i.e., SSP4) will likely result in less pressure on the habitats of species.

A gradual change in management of natural grasslands into high intensively used grasslands and eventually into permanent pastures might occur differently across the five republics as they will experience different socio-economic developments. Moreover, such conversion would need large irrigation schemes that would cause immediate salinization, and ultimately land degradation (Lioubimtseva and Henebry 2009). These physical limitations are, however, beyond the scope of the GLOBIO model.

The extreme climate impact from RCP8.5 projected an increased biodiversity loss in the region. This associated impact is in line with recent studies that reported the negative effect of temperature increase on arid and semi-arid grasslands worldwide (Warren et al. 2011; Dangal et al. 2016). SSP5-RCP8.5 projected continuously increasing greenhouse-gas emissions over the entire century (Riahi et al. 2011) and a global mean temperature that likely exceeded $2{ }^{\circ} \mathrm{C}$ (IPCC 2013). In the absence of climate policy, this scenario is very unlikely to limit the global mean temperature increase to well below $2{ }^{\circ} \mathrm{C}$ above pre-industrial levels (i.e., Paris Agreement; UNFCCC 2015). Hence, the biodiversity losses in SSP3-RCP8.5 and SSP5-RCP8.5 that result from climate change are an urgent call to limit greenhouse-gas emissions worldwide to the lowest possible level.

Our study relied highly on qualitative assumptions from integrated assessment models and socio-economic scenarios to explore the future implications of land-use and climate changes on extensively used grasslands, which are part of one of the most common land-use classes in the world. Socio-economic scenarios in our analysis were based on detailed insights from regional stakeholders. Stakeholders' input results in more realistic regional scenario elements than the assumption based on global scenario studies. This likely catered for a more robust analysis.

When studying the 'meso scale', it is always challenging to strike a balance between local expert knowledge, detailed data, and process-based information, and area-covering data and

Table 2 Changes in mean species abundance for all scenarios for 2040, 2070, and 2100

\begin{tabular}{|c|c|c|c|c|c|c|c|c|c|c|c|c|c|}
\hline \multirow[t]{2}{*}{ Mean species abundance } & \multirow[t]{2}{*}{2010} & \multicolumn{3}{|l|}{ SSP1 } & \multicolumn{3}{|l|}{ SSP3 } & \multicolumn{3}{|l|}{ SSP4 } & \multicolumn{3}{|l|}{ SSP5 } \\
\hline & & 2040 & 2070 & 2100 & 2040 & 2070 & 2100 & 2040 & 2070 & 2100 & 2040 & 2070 & 2100 \\
\hline High & 94.4 & 49.4 & 48.9 & 49.6 & 54.0 & 53.2 & 55.6 & 56.9 & 57.3 & 57.4 & 49.0 & 41.0 & 34.0 \\
\hline Moderate & 2.2 & 37.6 & 37.5 & 38 & 38.5 & 0.1 & 0.1 & 41.6 & 41.4 & 41.4 & 36.8 & 35.0 & 33.3 \\
\hline Low & 3.4 & 4.5 & 10.9 & 3.7 & 4.0 & 40.9 & 42.1 & 1.5 & 1.2 & 1.0 & 4.2 & 9.0 & 13.7 \\
\hline Critical & 0.0 & 8.5 & 2.6 & 8.7 & 3.5 & 5.8 & 2.1 & 0.0 & 0.1 & 0.2 & 10.3 & 14.7 & 19.3 \\
\hline
\end{tabular}


generally applicable rules consistent with the model architecture. Inherently, applying a global model at regional scale will have more difficulties to include all regionally important processes. Yet, our results do indicate potential for biodiversity loss, certainly relative to other regions in the world. Other studies that used the GLOBIO model have indicated the importance of such applications (Trisurat et al. 2010; PBL 2012; CBD 2014; Kok et al. 2018).

Previous studies that assessed global land-use change in the SSPs (Popp et al. 2017; Riahi et al. 2017; Doelman et al. 2018) included additional socio-economic elements, such as land allocation of grassland or cropland expansion, consumer preferences, and food price sensitivities. Their results, however, showed similar trends in losses of natural land. This means that the main elements that are selected in our study, drive the larger changes in the land-use system. While the SSPs are not specifically designed to explore grassland systems, our relatively simple approach allowed to explore changes in this system. Other assumptions on land-use intensification or the effects of GDP growth could derive different biodiversity trends. Thus, the underlying assumptions and scenarios are crucial to assess consequences in grassland systems.

Previous studies that reported the effects of land-use change (Alkemade et al. 2013; Petz et al. 2014; Newbold et al. 2015) and climate change (Alkemade et al. 2009; Bütof et al. 2012; White et al. 2014) in other grassland regions concluded that biodiversity is projected to decline. Our study supports this notion but also hints at the potentially large biodiversity losses in the Central Asian grasslands across all scenarios. These grasslands seem more vulnerable.

While our results translate relevant information of socioeconomic and climate change drivers, more research is urgently needed to translate our findings into better management strategies for Central Asia's grasslands. We estimated biodiversity change in the Central Asian grasslands using a simple biodiversity model that assumed a linear relationship between socio-economic drivers and grazing intensification. The resulting trends clearly demonstrate the need for better landuse and biodiversity-conservation planning.

Acknowledgments The authors would like to acknowledge Anna Bronzes from the group Environmental Systems Analysis group at Wageningen University and Research for providing constructive feedback and advice on key scenario assumptions in our study.

Funding information The "Impacts and Risks from High-End Scenarios: Strategies for Innovative Solutions (IMPRESSIONS)" project (Grant Agreement 603416) from the EU FP7 program provided financial support to conduct this research.

\section{Compliance with ethical standards}

Conflict of interest The authors declare that they have no conflict of interest.
Open Access This article is licensed under a Creative Commons Attribution 4.0 International License, which permits use, sharing, adaptation, distribution and reproduction in any medium or format, as long as you give appropriate credit to the original author(s) and the source, provide a link to the Creative Commons licence, and indicate if changes were made. The images or other third party material in this article are included in the article's Creative Commons licence, unless indicated otherwise in a credit line to the material. If material is not included in the article's Creative Commons licence and your intended use is not permitted by statutory regulation or exceeds the permitted use, you will need to obtain permission directly from the copyright holder. To view a copy of this licence, visit http://creativecommons.org/licenses/by/4.0/.

\section{References}

Alkemade R, van Oorschot M, Miles L, Nellemann C, Bakkenes M, ten Brink B (2009) GLOBIO3: a framework to investigate options for reducing global terrestrial biodiversity loss. Ecosystems 12:374390. https://doi.org/10.1007/s10021-009-9229-5

Alkemade R, Reid RS, van den Berg M, de Leeuw J, Jeuken M (2013) Assessing the impacts of livestock production on biodiversity in rangeland ecosystems. Proc Natl Acad Sci 110:20900-20905. https://doi.org/10.1073/pnas.1011013108

Bartholomé E, Belward AS (2005) GLC2000: a new approach to global land cover mapping from Earth observation data. Int J Remote Sens 26:1959-1977. https://doi.org/10.1080/01431160412331291297

Brinkert A, Hölzel N, Sidorova TV, Kamp J (2016) Spontaneous steppe restoration on abandoned cropland in Kazakhstan: grazing affects successional pathways. Biodivers Conserv 25:2543-2561. https:// doi.org/10.1007/s10531-015-1020-7

Bütof A, von Riedmatten LR, Dormann CF, Scherer-Lorenzen M, Welk E, Bruelheide H (2012) The responses of grassland plants to experimentally simulated climate change depend on land use and region. Glob Chang Biol 18:127-137. https://doi.org/10.1111/j.1365-2486. 2011.02539.x

CBD (2014) Global biodiversity outlook 4. Secretariat of the Convention on Biological Diversity, Montreal

Chen F, Wang J, Jin L, Zhang Q, Li J, Chen J (2009) Rapid warming in mid-latitude central Asia for the past 100 years. Front Earth Sci China 3:42. https://doi.org/10.1007/s11707-009-0013-9

Chen T, Bao A, Jiapaer G, Guo H, Zheng G, Jiang L, Chang C, Tuerhanjiang L (2019) Disentangling the relative impacts of climate change and human activities on arid and semiarid grasslands in Central Asia during 1982-2015. Sci Total Environ 653:13111325. https://doi.org/10.1016/j.scitotenv.2018.11.058

Christensen L, Coughenour MB, Ellis JE, Chen ZZ (2004) Vulnerability of the Asian typical steppe to grazing and climate change. Clim Chang 63:351-368. https://doi.org/10.1023/B:CLIM.0000018513. 60904.fe

Dangal SRS, Tian H, Lu C, Pan S, Pederson N, Hessl A (2016) Synergistic effects of climate change and grazing on net primary production of Mongolian grasslands. Ecosphere 7:e01274-n/a. https://doi.org/10.1002/ecs2.1274

Dara A, Baumann M, Hölzel N, Hostert P, Kamp J, Müller D, Ullrich B, Kuemmerle T (2019) Post-soviet land-use change affected fire regimes on the Eurasian steppes. Ecosystems:1-14. https://doi.org/10. 1007/s10021-019-00447-w

de Beurs KM, Henebry GM, Owsley BC, Sokolik I (2015) Using multiple remote sensing perspectives to identify and attribute land surface dynamics in Central Asia 2001-2013. Remote Sens Environ 170: 48-61. https://doi.org/10.1016/j.rse.2015.08.018 
Doelman JC, Stehfest E, Tabeau A, van Meijl H, Lassaletta L, Gernaat DEHJ, Hermans K, Harmsen M, Daioglou V, Biemans H, van der Sluis S, van Vuuren DP (2018) Exploring SSP land-use dynamics using the IMAGE model: regional and gridded scenarios of land-use change and landbased climate change mitigation. Glob Environ Chang 48:119-135. https://doi.org/10.1016/j.gloenvcha.2017.11.014

FAO (2007) Subregional report on animal genetic resources: Central Asia. Annex to The State of the World's Animal Genetic Resources for Food and Agriculture Food and Agriculture Organization of the United Nations, Rome

Gintzburger G, Le Houérou HN, Toderich KN (2005) The steppes of middle Asia: post-1991 agricultural and rangeland adjustment. Arid Land Res Manage 19:215-239. https://doi.org/10.1080/ 15324980590951360

Hamidov A, Helming K, Balla D (2016) Impact of agricultural land use in Central Asia: a review. Agron Sustain Dev 36:6-23. https://doi.org/ 10.1007/s13593-015-0337-7

Hankerson BR, Schierhorn F, Prishchepov AV, Dong C, Eisfelder C, Müller D (2019) Modeling the spatial distribution of grazing intensity in Kazakhstan. PLoS One 14:e0210051. https://doi.org/10. 1371/journal.pone.0210051

Harrison PA, Jäger J, Frantzeskaki N, Berry P (2019) Understanding high-end climate change: from impacts to co-creating integrated and transformative solutions. Reg Environ Chang 19:621-627. https://doi.org/10.1007/s10113-019-01477-9

Herrero M, Thornton PK, Gerber P, Reid RS (2009) Livestock, livelihoods and the environment: understanding the trade-offs. Curr Opin Environ Sustain 1:111-120. https://doi.org/10.1016/j.cosust.2009. 10.003

Hu Z, Zhang C, Hu Q, Tian H (2014) Temperature changes in Central Asia from 1979 to 2011 based on multiple datasets. J Clim 27:11431167. https://doi.org/10.1175/jcli-d-13-00064.1

IPBES (2016) Summary for policymakers of the methodological assessment report on scenarios and models of biodiversity and ecosystem services of the Intergovernmental Science-Policy Platform on Biodiversity and Ecosystem Services. Secretariat of the Intergovernmental Science-Policy Platform on Biodiversity and Ecosystem Services, Bonn

IPBES (2018) The IPBES regional assessment report on biodiversity and ecosystem services for Europe and Central Asia. Secretariat of the Intergovernmental Science-Policy Platform on Biodiversity and Ecosystem Services, Bonn

IPBES (2019) Summary for policymakers of the global assessment report on biodiversity and ecosystem services of the intergovernmental science-policy platform on biodiversity and ecosystem services. Bonn

IPCC (2013) Climate change 2013: the physical science basis. In: Contribution of Working Group I to the Fifth Assessment Report of the Intergovernmental Panel on Climate Change. Cambridge University Press Cambridge, Cambridge

IUCN (2019) The IUCN red list of threatened species Version 2018-2

Jones B, O'Neill B (2013) Historically grounded spatial population projections for the continental United States. Environ Res Lett 8: 044021. https://doi.org/10.1088/1748-9326/8/4/044021

Kamp J, Sheldon RD, Koshkin MA, Donald PF, Biedermann R (2009) Post-Soviet steppe management causes pronounced synanthropy in the globally threatened sociable Lapwing Vanellus gregarius. Ibis 151:452-463. https://doi.org/10.1111/j.1474-919X.2009.00938.x

Kamp J, Urazaliev R, Donald PF, Hölzel N (2011) Post-Soviet agricultural change predicts future declines after recent recovery in Eurasian steppe bird populations. Biol Conserv 144:2607-2614. https://doi.org/10.1016/j.biocon.2011.07.010

Kamp J, Siderova TV, Salemgareev AR, Urazaliev RS, Donald PF, Hölzel N (2012) Niche separation of larks (Alaudidae) and agricultural change on the drylands of the former Soviet Union. Agric. Ecosyst. Environ. 155: 41-49. https://doi.org/10.1016/j.agee.2012.03.023
Kamp J, Koshkin MA, Bragina TM, Katzner TE, Milner-Gulland EJ, Schreiber D, Sheldon R, Shmalenko A, Smelansky I, Terraube J, Urazaliev R (2016) Persistent and novel threats to the biodiversity of Kazakhstan's steppes and semi-deserts. Biodivers Conserv 25: 2521-2541. https://doi.org/10.1007/s10531-016-1083-0

Kok K, Pedde S (2016) IMPRESSIONS socio-economic scenarios. IMPRESSIONS project, Environmental Change Institute, Oxford

Kok MTJ, Alkemade R, Bakkenes M, van Eerdt M, Janse J, Mandryk M, Kram T, Lazarova T, Meijer J, van Oorschot M, Westhoek H, van der Zagt R, van der Berg M, van der Esch S, Prins A-G, van Vuuren DP (2018) Pathways for agriculture and forestry to contribute to terrestrial biodiversity conservation: a global scenario-study. Biol Conserv 221: 137-150. https://doi.org/10.1016/j.biocon.2018.03.003

Lioubimtseva E, Henebry GM (2009) Climate and environmental change in arid Central Asia: impacts, vulnerability, and adaptations. J Arid Environ 73:963-977. https://doi.org/10.1016/j.jaridenv.2009.04.022

MA (2005) Ecosystems and human well-being. Millenium Ecosystem Assessment, Washington, DC

Malcolm J, Liu C, Neilson R, Hansen L, Hannah L (2006) Global warming and extinctions of endemic species from biodiversity hotspots. Conserv Biol 20:538-548. https://doi.org/10.1111/j.15231739.2006.00364.x

Mallon DP, Zhigang J (2009) Grazers on the plains: challenges and prospects for large herbivores in Central Asia. J Appl Ecol 46:516-519. https://doi.org/10.1111/j.1365-2664.2009.01654.x

Mirzabaev A (2013) Impacts of weather variability and climate change on agricultural revenues in Central Asia. Q J Int Agric 25:237-252. https://www.agrar.hu-berlin.de/de/institut/departments/daoe/publ/ qjia/contents/2013/3-13/Mirzabaev

Mirzabaev A, Ahmed M, Werner J, Pender J, Louhaichi M (2015) Rangelands of Central Asia: challenges and opportunities. Journal of Arid Land 8:93-108. https://doi.org/10.1007/s40333-015-0057-5

Newbold T (2018) Future effects of climate and land-use change on terrestrial vertebrate community diversity under different scenarios. Proc R Soc Lond, Ser B: Biol Sci 285:20180792. https://doi.org/10. 1098/rspb.2018.0792

Newbold T, Hudson LN, Hill SLL, Contu S, Lysenko I, Senior RA, Borger L, Bennett DJ, Choimes A, Collen B, Day J, De Palma A, Diaz S, Echeverria-Londono S, Edgar MJ, Feldman A, Garon M, Harrison MLK, Alhusseini T, Ingram DJ, Itescu Y, Kattge J, Kemp V, Kirkpatrick L, Kleyer M, Correia DLP, Martin CD, Meiri S, Novosolov M, Pan Y, Phillips HRP, Purves DW, Robinson A, Simpson J, Tuck SL, Weiher E, White HJ, Ewers RM, Mace GM, Scharlemann JPW, Purvis A (2015) Global effects of land use on local terrestrial biodiversity. Nature 520:45-50. https://doi.org/10. 1038/nature14324

Newbold T, Hudson LN, Arnell AP, Contu S, De Palma A, Ferrier S, Hill SLL, Hoskins AJ, Lysenko I, Phillips HRP, Burton VJ, Chng CWT, Emerson S, Gao D, Pask-Hale G, Hutton J, Jung M, Sanchez-Ortiz K, Simmons BI, Whitmee S, Zhang H, Scharlemann JPW, Purvis A (2016) Has land use pushed terrestrial biodiversity beyond the planetary boundary? A global assessment. Science 353:288-291. https:// doi.org/10.1126/science.aaf2201

Nunez S, Arets E, Alkemade R, Verwer C, Leemans R (2019) Assessing the impacts of climate change on biodiversity: is below $2{ }^{\circ} \mathrm{C}$ enough? Clim Change 154:351-365. https://doi.org/10.1007/ s10584-019-02420-x

O’Neill BC, Kriegler E, Riahi K, Ebi KL, Hallegatte S, Carter TR, Mathur R, van Vuuren DP (2014) A new scenario framework for climate change research: the concept of shared socioeconomic pathways. Clim Chang 122:387-400. https://doi.org/10.1007/s10584013-0905-2

Olson D, Dinerstein E, Wikramanayake E, Burgess N, Powell G, Underwood E, D'Amico J, Itoua I, Strand H, Morrison J, Loucks C, Allnutt T, Ricketts T, Kura Y, Lamoreux J, Wettengel W, Hedao P, Kassem K (2001) Terrestrial ecoregions of the worlds: a new map of 
life on Earth. Bioscience 51:933-938. https://doi.org/10.1641/00063568(2001)051[0933:teotwa]2.0.co;2

PBL (2012) Roads from Rio+20. Pathways to achieve global sustainability goals by 2050. Netherlands Environmental Assessment Agency, The Hague 286

Pereira HM, Leadley PW, Proença V, Alkemade R, Scharlemann JPW, Fernandez-Manjarrés JF, Araújo MB, Balvanera P, Biggs R, Cheung WWL, Chini L, Cooper HD, Gilman EL, Guénette S, Hurtt GC, Huntington HP, Mace GM, Oberdorff T, Revenga C, Rodrigues P, Scholes RJ, Sumaila UR, Walpole M (2010) Scenarios for global biodiversity in the 21 st century. Science 330:1496-1501. https://doi. org/10.1126/science. 1196624

Petz K, Alkemade R, Bakkenes M, Schulp CJE, van der Velde M, Leemans R (2014) Mapping and modelling trade-offs and synergies between grazing intensity and ecosystem services in rangelands using global-scale datasets and models. Glob Environ Chang 29: 223-234. https://doi.org/10.1016/j.gloenvcha.2014.08.007

Popp A, Calvin K, Fujimori S, Havlik P, Humpenöder F, Stehfest E, Bodirsky BL, Dietrich JP, Doelmann JC, Gusti M, Hasegawa T, Kyle P, Obersteiner M, Tabeau A, Takahashi K, Valin H, Waldhoff S, Weindl I, Wise M, Kriegler E, Lotze-Campen H, Fricko O, Riahi K, Vuuren DP (2017) Land-use futures in the shared socioeconomic pathways. Glob Environ Chang 42:331-345. https://doi. org/10.1016/j.gloenvcha.2016.10.002

Riahi K, Rao S, Krey V, Cho C, Chirkov V, Fischer G, Kindermann G, Nakicenovic N, Rafaj P (2011) RCP 8.5-a scenario of comparatively high greenhouse gas emissions. Clim Change 109:33. https:// doi.org/10.1007/s10584-011-0149-y

Riahi K, van Vuuren DP, Kriegler E, Edmonds J, O’Neill BC, Fujimori S, Bauer N, Calvin K, Dellink R, Fricko O, Lutz W, Popp A, Cuaresma JC, Kc S, Leimbach M, Jiang L, Kram T, Rao S, Emmerling J, Ebi K, Hasegawa T, Havlik P, Humpenöder F, Da Silva LA, Smith S, Stehfest E, Bosetti V, Eom J, Gernaat D, Masui T, Rogelj J, Strefler J, Drouet L, Krey V, Luderer G, Harmsen M, Takahashi K, Baumstark L, Doelman JC, Kainuma M, Klimont Z, Marangoni G, Lotze-Campen H, Obersteiner M, Tabeau A, Tavoni M (2017) The shared socioeconomic pathways and their energy, land use, and greenhouse gas emissions implications: an overview. Glob Environ Chang 42:153-168. https:// doi.org/10.1016/j.gloenvcha.2016.05.009

Robinson S, Milner-Gulland EJ, Alimaev I (2003) Rangeland degradation in Kazakhstan during the Soviet era: re-examining the evidence. J Arid Environ 53:419-439. https://doi.org/10.1006/jare.2002.1047

Robinson S, Kerven C, Behnke R, Kushenov K, Milner-Gulland EJ (2016) The changing role of bio-physical and socio-economic drivers in determining livestock distributions: a historical perspective from Kazakhstan. Agric Syst 143:169-182. https://doi.org/10. 1016/j.agsy.2015.12.018

Sánchez-Zapata JA, Carrete M, Gravilov A, Sklyarenko S, Ceballos O, Donázar JA, Hiraldo F (2003) Land use changes and raptor conservation in steppe habitats of Eastern Kazakhstan. Biol Conserv 111: 71-77. https://doi.org/10.1016/S0006-3207(02)00251-3

Schipper AM, Hilbers JP, Meijer JR, Antão LH, Benítez-López A, de Jonge MMJ, Leemans LH, Scheper E, Alkemade R, Doelman JC, Mylius S, Stehfest E, van Vuuren DP, van Zeist W-J, Huijbregts MAJ (2019) Projecting terrestrial biodiversity intactness with GLOBIO 4. Glob Chang Biol. https://doi.org/10.1111/gcb.14848

Scholes RJ, Biggs R (2005) A biodiversity intactness index. Nature 434: 45-49. https://doi.org/10.1038/nature03289

Singh NJ, Grachev IA, Bekenov AB, Milner-Gulland EJ (2010) Tracking greenery across a latitudinal gradient in central Asia-the migration of the saiga antelope. Divers Distrib 16:663-675. https://doi.org/10. $1111 / j .1472-4642.2010 .00671 . x$

Stehfest E, van Vuuren D, Kram T, Bouwman L, Alkemade R, Bakkenes M, Biemans H, Bouwman A, den Elzen M, Janse J, Lucas P, van Minnen J, Müller C, Gerdien Prins A (2014) Integrated assessment of global environmental change with IMAGE 3.0. Model
Description and Policy Applications. PBL Netherlands Environmental Assessment Agency, The Hague

Suleimenov M (2014) Trends in the agriculture of Central Asia and implications for rangelands and croplands. In: Novel Measurement and Assessment Tools for Monitoring and Management of Land and Water Resources in Agricultural Landscapes of Central Asia. Springer International Publishing, Cham, pp 91-105

Thomas C, Cameron A, Green RE, Bakkenes M, Beaumont LJ, Collingham YC, Erasmus BFN, de Siqueira MF, Grainger A, Hannah L, Hughes L, Huntley B, van Jaarsveld AS, Midgley GF, Miles L, Ortega-Huerta MA, Townsend Peterson A, Phillips OL, Williams SE (2004) Extinction risk from climate change. Nature 427:145-148. https://doi.org/10.1038/nature02121

Thornton PK (2010) Livestock production: recent trends, future prospects. Philos Trans R Soc B: Biol Sci 365:2853-2867. https://doi. org/10.1098/rstb.2010.0134

Trisurat Y, Alkemade R, Verburg PH (2010) Projecting land-use change and its consequences for biodiversity in Northern Thailand. Environ Manag 45:626-639. https://doi.org/10.1007/s00267-010-9438-x

UNFCCC (2015) Adoption of the Paris Agreement. Report No. FCCC/CP/2015/L.9/Rev.1. UNFCCC, Bonn, http://unfccc.int/ resource/docs/2015/cop21/eng/109r01.pdf

van Vuuren D, Edmonds J, Kainuma M, Riahi K, Thomson A, Hibbard K, Hurtt GC, Kram T, Krey V, Lamarque J-F (2011) The representative concentration pathways: an overview. Clim Chang 109:5-31. https://doi.org/10.1007/s10584-011-0148-Z

Verburg PH, Crossman N, Ellis EC, Heinimann A, Hostert P, Mertz O, Nagendra H, Sikor T, Erb K-H, Golubiewski N, Grau R, Grove M, Konaté S, Meyfroidt P, Parker DC, Chowdhury RR, Shibata H, Thomson A, Zhen L (2015) Land system science and sustainable development of the earth system: a global land project perspective. Anthropocene 12:29-41. https://doi.org/10.1016/j.ancene.2015.09.004

Wang Y, Shiyomi M, Tsuiki M, Tsutsumi M, Yu X, Yi R (2002) Spatial heterogeneity of vegetation under different grazing intensities in the Northwest Heilongiiang steppe of China. Agric. Ecosyst Environ 90:217-229. https://doi.org/10.1016/S0167-8809(01)00217-1

Warren R, Price J, Fischlin A, de la Nava SS, Midgley G (2011) Increasing impacts of climate change upon ecosystems with increasing global mean temperature rise. Clim Chang 106:141-177. https:// doi.org/10.1007/s10584-010-9923-5

White SR, Bork EW, Cahill JF (2014) Direct and indirect drivers of plant diversity responses to climate and clipping across northern temperate grassland. Ecology 95:3093-3103. https://doi.org/10.1890/140144.1

World Bank (2019). World Bank Open Data

World Bank (2016). World Bank Open Data. https://data.worldbank.org/

Yu Y, Pi Y, Yu X, Ta Z, Sun L, Disse M, Zeng F, Li Y, Chen X, Yu R (2019) Climate change, water resources and sustainable development in the arid and semi-arid lands of Central Asia in the past 30 years. Journal of Arid Land 11:1-14. https://doi.org/10.1007/ s40333-018-0073-3

ZEN (2011) Biodiversity in Central Asia: a visual synthesis. Zoï Environment Network

Zhang G, Biradar CM, Xiao X, Dong J, Zhou Y, Qin Y, Zhang Y, Liu F, Ding M, Thomas RJ (2018a) Exacerbated grassland degradation and desertification in Central Asia during 2000-2014. Ecol Appl 28: 442-456. https://doi.org/10.1002/eap.1660

Zhang R, Liang T, Guo J, Xie H, Feng Q, Aimaiti Y (2018b) Grassland dynamics in response to climate change and human activities in Xinjiang from 2000 to 2014. Sci Rep 8:2888. https://doi.org/10. 1038/s41598-018-21089-3

Publisher's note Springer Nature remains neutral with regard to jurisdictional claims in published maps and institutional affiliations. 